Reprod. Nutr. Dévelop., 1981, 21 (3), 371-375.

\title{
A rapid technique for the histological examination of large ovarian follicles
}

\author{
par M. A. DRIANCOURT, J. C. MARIANA, E. PALMER \\ Station de Physiologie de la Reproduction, I.N.R.A., \\ Nouzilly, 37380 Monnaie, France.
}

Summary. A rapid technique for counting and classifying large ovarian follicles of domestic animals is described. Using a cryostat, $250-\mu \mathrm{m}$ thick sections were cut from the frozen ovary; an image of the surface of each ovarian section was recorded on videotape. By replaying the videotape, the largest profile of each follicle larger than $1 \mathrm{~mm}$ in diameter was readily identified and measured. The presence or absence of atresia was determined by applying standard histological methods to fragments of individual follicles taken from the frozen sections. The results obtained are similar to those found using previous methods and demand only one-quarter of the time.

\section{Introduction.}

Macroscopic observation has been widely used to study changes in the large follicle population in large domestic animals (ewe : Hutchinson and Robertson, 1966 ; Dufour and Matton, 1977 ; cow : Desjardins and Hafs, 1969 ; Testart, 1972 ; mare : Hammond and Wodzicki, 1941 ; Warszawsky et al., 1972). Such observations do not give a true picture of the dynamics of follicular growth and regression since information on atresia is lacking.

We present here a new technique that provides data on atresia and on follicle number and size but is much more rapid than the routine histological methods.

\section{Technique.}

Mares, cows and heifers in which superovulation had been induced several days earlier were slaughtered and their ovaries rapidly collected and fixed in Carnoy glycerol fixative $(90: 10 \mathrm{v} / \mathrm{v})$. After 4 days in this fixative, they were transferred to a solution of glycerol (1 part) in 25 p. 100 ( $v / v)$ acetic acid (9 parts) for rehydration. After 6 days, they were removed, quickly frozen in dry-ice and cut into $250-\mu \mathrm{m}$ sections with a cryostat (Kryomat, Leitz) at $-25^{\circ} \mathrm{C}$.

Immediately after each $250-\mu \mathrm{m}$ section of ovary had been cut, an image of the ovarian surface was recorded using a television camera and video-recorder (fig. 1). 


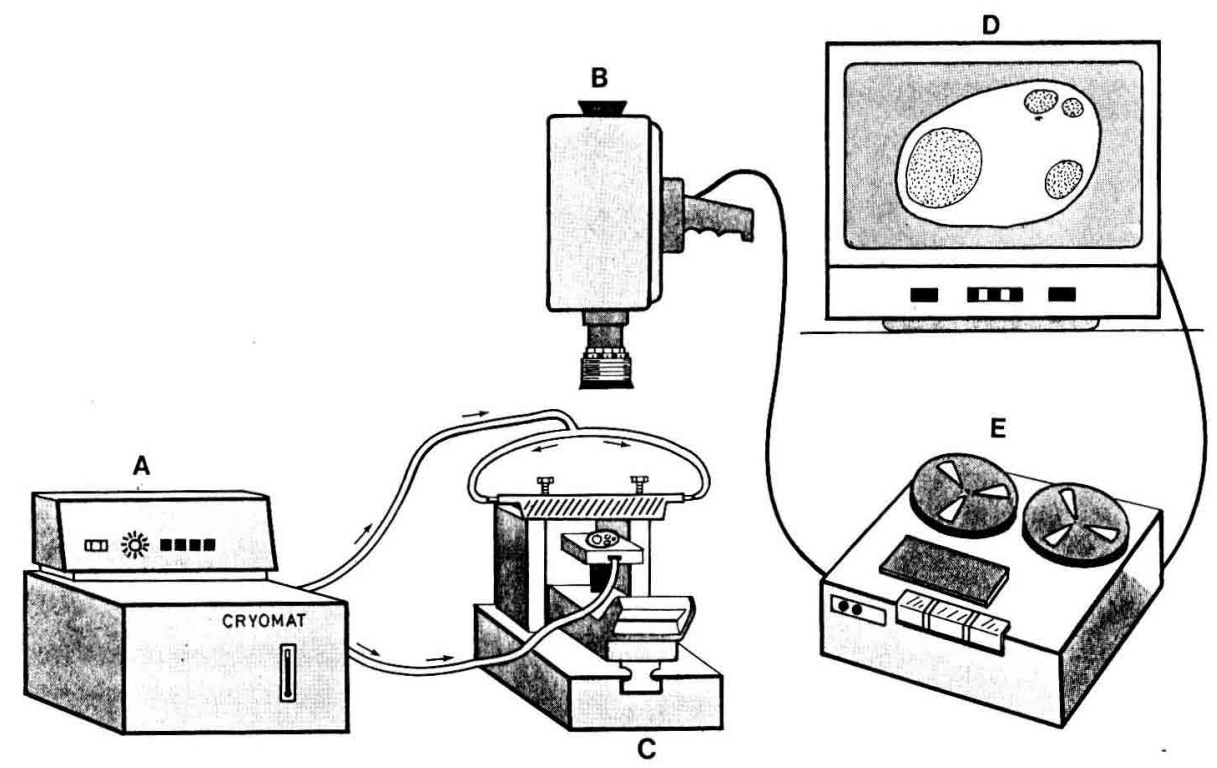

FIG. 1. - Experimental design. A : Cryomat ; B : Television camera with a lens of $90-\mathrm{mm}$ focal length ; $C$ : Microtome; $D$ : Black and white video-monitor; $E$ : Video-recorder.

Successive images were then displayed on a video-monitor to reveal the appearance and disappearance of the follicular profiles and to permit rapid identification and measurement (two diameters at right angles to each other) of the largest profile.

Using this technique, all the follicles with a mean diameter larger than $1 \mathrm{~mm}$ were measured and counted. As soon as each follicle was revealed by the removal of a 250- $\mu \mathrm{m}$ section, it was covered by a piece of white paper with an identification number; this number appeared when the videotape was replayed, thus ensuring that each follicle was counted only once.

Atresia was evaluated using routine histological methods on fragments of individual follicles dissected from the $250-\mu \mathrm{m}$ sections. These fragments were fixed in Bouin-Holland fixative, dehydrated, embedded in paraffin and cut into $8-\mu \mathrm{m}$ sections which were then stained with hematoxylin. A follicle was classed as atretic if the section studied contained more than five pyknotic nuclei.

\section{Results and discussion.}

This technique, in order to be useful, should permit healthy and atretic follicles to be recognized and accurately counted.

Figure 2 shows a normal follicle with mitotic figures in some of the healthy granulosa cells, whereas figure 3 shows an atretic follicle with clearly visible pyknotic bodies. 

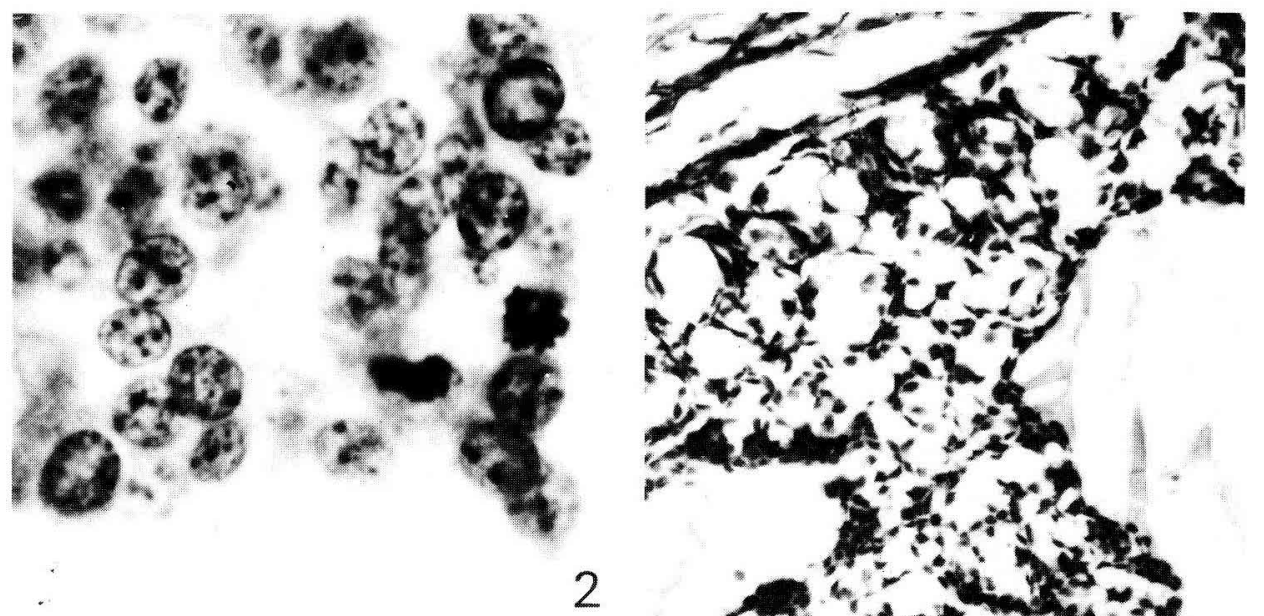

3
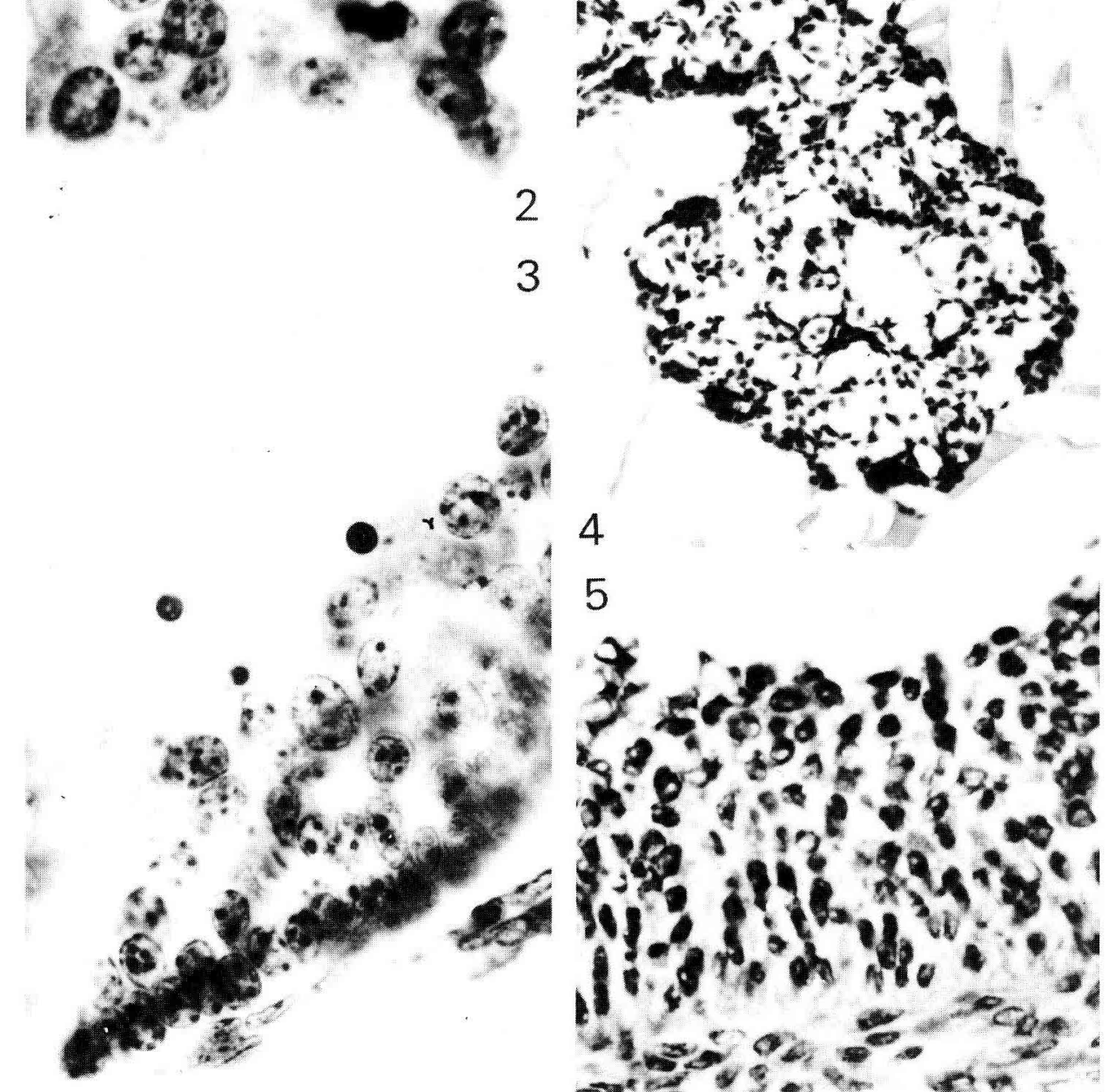

FIG. 2. - Apparently healthy cells observed using the rapid technique (mare ovary $\times 1200$ ).

FIG. 3. - Granulosa layer of an atretic follicle observed using the rapid. technique (mare ovary $\times 1200$ ).

FIG. 4. - Freeze injury to granulosa cells in an ewe ovary that was neither fixed nor glycerolized $(\times 200)$.

FIG. 5. - Freeze injury to granulosa cells in a cow ovary that was fixed but not glycerolized $(\times 600)$. 
Freezing never induced pyknosis in the granulosa cells; any damage it caused was distinctly different in appearance from that of pyknosis.

Figure 4 shows results obtained using an ovary that was frozen without prior fixation or glycerolization. In most cases, the granulosa layer was completely destroyed. Figure 5 shows the effect of freezing an ovary that was fixed but not glycerolized ; the basal membrane is disorganized and the nuclei of the granulosa cells have been markedly altered. Glycerol may protect the tissues by lowering the freezing temperature of intracellular water, by modifying the shape of ice crystals (Shimada and Asahina, 1975 ; Sherman and Liu, 1976) and by stabilizing the membranes (Maurer, 1978).

The same follicle should not be counted twice, if accurate counts are to be obtained. It is easy to be accurate using the species studied because the small number of follicles in the ovaries permits them to be individually identified reliably. To be sure that the small follicles were not overlooked, we compared the number of small $(1-4 \mathrm{~mm})$ follicles in eight mare ovaries counted by our rapid technique with the number in eight ovaries obtained from other mares and counted by the standard histological methods. Similar numbers $(7.5+0.8$ (SD) and $8.1+1.1$, respectively) were found using the two methods.

This technique gives data on the number, size and atresia of all follicles larger than $1 \mathrm{~mm}$ in diameter within 2 weeks of slaughter, whereas the standard methods require 2 months. The high speed and accuracy of the rapid technique makes it a useful tool for studying the large follicle population in large domestic animals and thus for improving our understanding of follicular growth and stimulation.

Reçu en juillet 1980.

Accepté en août 1980.

Acknowledgements. - The authors thank Dr. B. Gibson for his help in preparing the English translation.

Résumé. Une technique rapide, permettant de compter et de mesurer les gros follicules ovariens chez les animaux domestiques, est décrite : l'ovaire est coupé à congélation à $250 \mu \mathrm{m}$ d'épaisseur et après chaque coupe, une image de la surface de l'ovaire est enregistrée sur un magnétoscope. En repassant la bande du magnétoscope, on trouve, pour chaque follicule de taille supérieure à $1 \mathrm{~mm}$ de diamètre, sa plus grosse section ; le diamètre de ce follicule est mesuré. L'atrésie est évaluée en traitant des fragments de follicules, obtenus à partir des sections à congélation, selon les techniques de l'histologie classique. Par cette technique, on obtient des résultats équivalents à ceux obtenus en histologie classique, en un temps beaucoup plus bref.

\section{References}

DESJARDINS C., HAFS H. D., 1969. Maturation of bovine female genitalia from birth through puberty, J. anim. Sci., 28, 502-507.

DUFOUR J. J., MATTON P., 1977. Identification of ovarian follicles at estrus and development of their ensuing corpora lutea in single and multiple ovulating ewes on two feeding regimes. Can. J. anim. Sci., 57, 647-652. 
HAMMOND J., WODZICKI K., 1941. Anatomical and histological changes during the oestrous cycle in the mare. Proc. roy. Soc. London, 130, 1-23.

HUTCHINSON J. S., ROBERTSON H. A., 1966. The growth of the follicle and corpus luteum in the ovary of the sheep. Res. vet. Sci., 7, 17.

MAURER R. R., 1978. Freezing mammalian embryos : a review of techniques. Theriogenology, 9, 4559.

SHERMAN J. K., LIU K. C., 1976. Relation of ice formation to ultrastructural cryoinjury and cryoprotection of rough endoplasmic reticulum. Cryobiology, 13, 599-608.

SHIMADA K., ASAHINA E., 1975. Vizualization in intracellular ice crystals formed in very rapidly frozen cells at $-27^{\circ} \mathrm{C}$. Cryobiology, 12, 209-218.

TESTART J., 1972. Réponse folliculaire du veau femelle impubère à divers traitements de gonadotropine sérique associée ou non à un progesiagène. Ann. Biol. anim. Bioch. Biophys., 12, 397-409.

WARSZAWSKY L. F., PARKER W. G., FIRST N. L., GINTHER O. J., 1972. Gross changes of internal genifalia during the oestrous cycle of the mare. Am. J. vet. Res., 33, 19-26. 